\title{
Electron ionization mass spectrometry of difurfuryl diamines
}

\author{
Alain Lesimple ${ }^{\mathrm{a}}$, Yves Le Bigot ${ }^{\mathrm{a}}$, Michel Delmas ${ }^{\mathrm{a}}$ and Joseph Banoub ${ }^{\mathrm{b}}$ \\ ${ }^{a}$ Laboratoire de Catalyse, Chimie Fine et Polymères, Institut National Polytechnique de Toulouse, Ecole \\ Nationale Supérieure de Chimie de Toulouse, 118, Route de Narbonne, 31077 Toulouse cedex 4, France \\ ${ }^{\mathrm{b}}$ Department Fisheries and Oceans, Science Branch, Environmental Sciences Division, P.O. Box 5667, \\ St John's, Newfoundland, Canada A1C 5X1, and Department of Biochemistry, Memorial University of \\ Newfoundland, St John's, Newfoundland, Canada A1B $3 X 9$
}

\begin{abstract}
Electron impact mass spectrometry (ei-ms) has aided the structural characterization of a novel series of synthetic difuranic diamines and permitted the comparison with a previous study employing electrospray ionization mass spectrometry. As expected, the molecular radical ion was inexistant in this series of compounds and the fragmentation routes of the molecular radical ion were governed either by homolytic cleavage of the radical $\mathrm{R}_{2}$ or by heterolytic loss of $\mathrm{NH}_{3}$ to give their respective base peaks.
\end{abstract}

\section{Introduction}

Synthetic polymers are usually obtained from fossil sources [1]. Furanic rings, when integrated into different macromolecules, confer specific properties on these molecules [2]. We have synthesized a novel series of difuranic diamines [3-5] that could be considered as intermediates of choice for the preparation of polyurethane derivatives [6-8]. Moreover, the presence of these two reactive functions promises a potential use for these molecules as cross-linking agents in the synthesis of polymeric macromolecules. These diamines can also incorporated directly in structures like polyamides [9], Schiff polybases [10], polyamines, polyimides and as curing agents for epoxy resins [11]. We have previously described the structural characterization and differentiation by electrospray tandem mass spectrometry of difuranic diamine hydrochlorides of compounds 1-6 [12]. In this rationale the possible fragmentation routes were studied by controlled collisionally activated dissociation (CAD) initiated by cone-voltage fragmentation. Low energy CAD tandem mass spectrometry analyses confirmed the characteristic fingerprints patterns of the decomposition of the protonated pseudomoleculary ion $\left[\mathrm{M}+\mathrm{H}^{+}-2 \mathrm{HCl}\right]^{+}$.

We have previously described the one step synthesis of difurfurylic diamines by condensation in an acidic medium of furfurylamine with a carbonylated compound [3-5]. Although their first synthesis dates back to 1984 [13], it seems that no study of their fragmentation by mass spectrometry using electronic impact $(70 \mathrm{eV})$ ionization (ei-ms) was described. We therefore propose to present and discuss their ei-ms and to compare the results with that obtained using the state-of-the-art electrospray mass spectrometry.

In this work, we shall study the behavior under electronic impact of the various following difurfurylic diamines: 


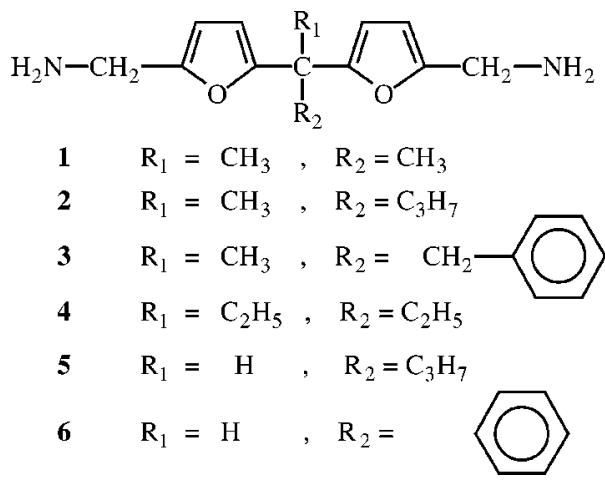

$\mathrm{R}_{2}$ : substituent with the greater number of carbon atoms.

\section{Experimental}

The compounds studied were prepared and purified as described previously [5]. All mass spectrometric measurements were performed on a NERMAG R 10-10 mass spectrometer operating in the EI mode $(70 \mathrm{eV})$. Samples were introduced by using a direct probe inlet.

\section{Results and discussion}

The $70 \mathrm{eV}$ ei-ms of the compounds $\mathbf{1}$ to $\mathbf{6}$ are reported in Table 1.

The study of the ei-ms of these molecules, contrary to the spectra of the difuranic compounds spectra described in the literature $[14,15]$, showed that the molecular radical ion $\mathbf{M}^{+\cdot}$ is very unstable. Actually, this molecular radical ion degrades very rapidly by two different routes presented in Fig. 1. Thus $\mathrm{M}^{+}$. fragments either by homolytic cleavage of the $\mathrm{R}_{2}$ group (substituent with the greater number of carbon atom), leading to the positive ion $\left[\mathrm{M}^{+\cdot}-\mathrm{R}_{2}\right]^{+}$, in the case of compounds $2,3,4$ or by heterolytic cleavage and loss of ammonia leading to the radical ion $\left[\mathrm{M}^{+\cdot}-\mathrm{NH}_{3}\right]^{+\cdot}$, in the case of compounds $\mathbf{1 , 5 , 6}$. The base peak always occurs from one of these two ions.

The loss of ammonia in this series of compounds is to be noted, in as much this phenomenon was only exceptionally observed in the literature [16,17], and usually induces the formation of low intensity peaks. Indeed the mass spectra of primary benzylamines described in the literature [17], produces the most prominent peaks $\left[\mathrm{M}^{+\cdot}\right.$ and $\left[\mathrm{M}^{\cdot+}-\mathrm{H}^{\cdot}\right]^{+}$which loses a molecule of ammonia to give a peak of less than $10 \%$ intensity.

Table 1

Electron Impact mass spectra of difurfurylic diamines

\begin{tabular}{cl}
\hline Compound & \multicolumn{1}{c}{$m / z(\%)$} \\
\hline $\mathbf{1}$ & $234(0.5), 219(17), 218(3), 217(100), 202(52), 175(28), 96(22), 68(5), 39(5)$ and 30(22) \\
$\mathbf{2}$ & $246(8), 245(49), 219(100), 202(27), 175(21), 96(13), 68(6), 39(8)$ and 30(83) \\
$\mathbf{3}$ & $294(1), 219(100), 202(10), 175(13), 96(8), 68(3), 39(4)$ and 30(32) \\
$\mathbf{4}$ & $262(0,4), 246(4), 245(33), 233(100), 216(18), 189(18), 96(19), 68(4), 39(5)$ and 30(51) \\
$\mathbf{5}$ & $248(0,8), 232(10), 231(100), 205(84), 188(68), 161(62), 96(25), 68(11), 39(12)$ and 30(98) \\
$\mathbf{6}$ & 266(5), 265(100), 205(1), 188(5), 161(3),96(34),68(4), 39(6) and 30(64) \\
\hline
\end{tabular}


A. Lesimple et al. / Electron ionization mass spectrometry of difurfuryl diamines
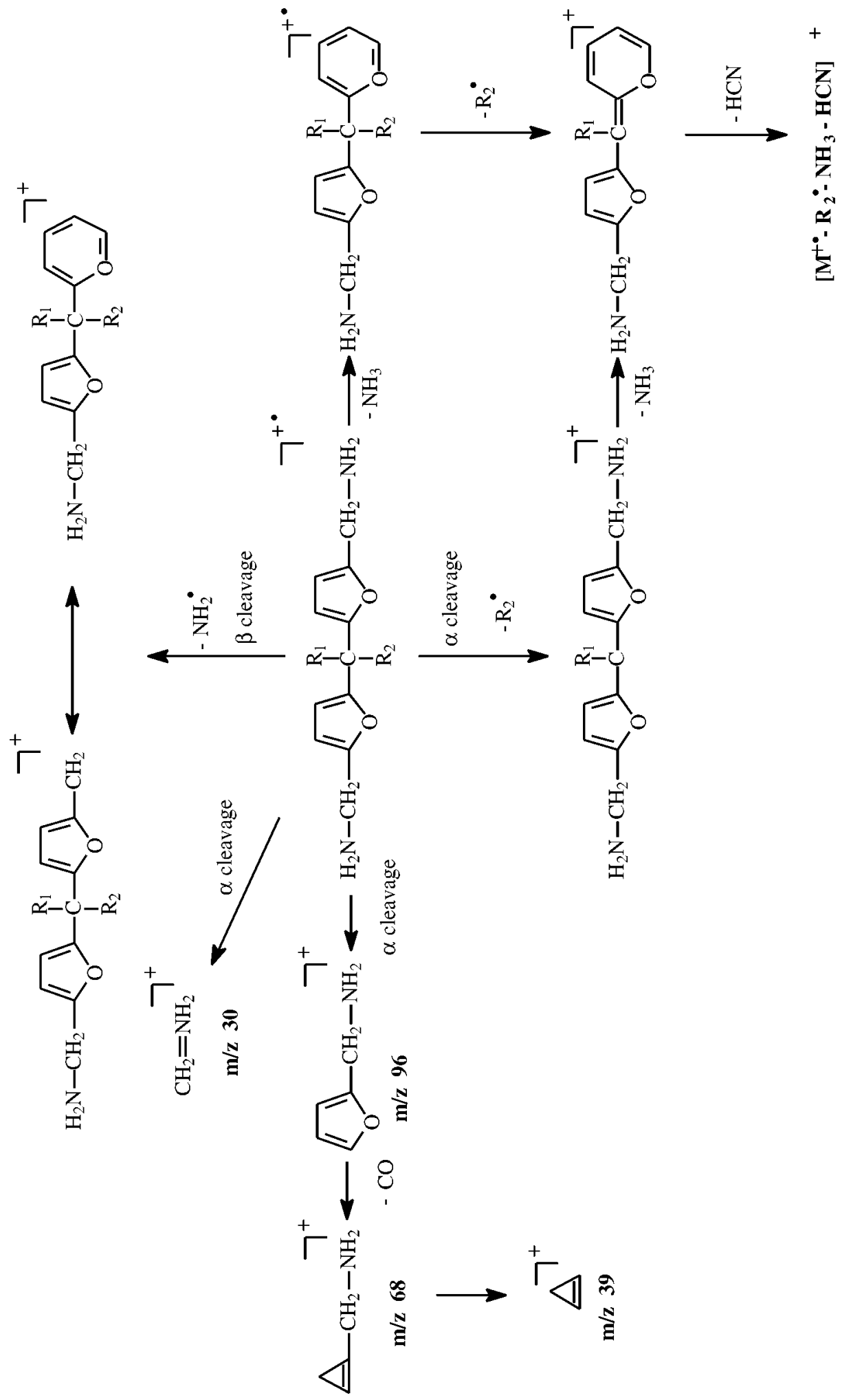
Table 2

Thermodynamical stabilization energies, $S E^{0}$, and bond dissociation energies, $D_{298}$, corresponding to the radical species losses from 1-6

\begin{tabular}{|c|c|c|}
\hline $\begin{array}{c}\text { Radical } \\
\mathrm{R}_{2}^{\cdot}\end{array}$ & $\begin{array}{l}\text { Thermodynamical stabilization } \\
\text { energies }^{\mathrm{a}}, S E^{0}\left(\mathrm{kcal}^{\mathrm{m}} \mathrm{mole}^{-1}\right)\end{array}$ & $\begin{array}{c}\text { Bond dissociation energies }{ }^{\mathrm{b}}, D_{298} \\
\left(\mathrm{kcal}^{\mathrm{mole}}{ }^{-1}\right)\end{array}$ \\
\hline $\mathrm{CH}_{3}^{-}$ & -1.67 & 104 \\
\hline \multirow[t]{2}{*}{$\mathrm{C}_{3} \mathrm{H}_{7}$} & 1.79 & 98 \\
\hline & 12.8 & 85 \\
\hline \multirow{2}{*}{$\mathrm{C}_{2} \mathrm{H}_{5}^{\cdot}$} & 2.11 & 98 \\
\hline & -10.27 & 104 \\
\hline
\end{tabular}

The intensities of the fragment ions $\left[\mathrm{M}^{+\cdot}-\mathrm{R}_{2}\right]^{+}$obtained by the loss of the $\mathrm{R}_{2}^{\cdot}$ radical in compounds $\mathbf{1}$ to $\mathbf{6}$, follows the ease of formation of the corresponding radical $R_{2}$ (Table 2). This loss is in accordance with the literature data concerning the bond-dissociation energies, $D[18,19]$, and the thermodynamical stabilization energies, $S E$ [20] (Table 2). The highest intensity for the $\left[\mathrm{M}^{+\cdot}-\mathrm{R}_{2}\right]^{+}$radical ion fragment, obtained by loss of the $\mathrm{R}_{2}$, was observed in the case of the benzyl compound, 3 . In this manner, for the compounds $\mathbf{1}$ and $\mathbf{3}$, which give the same ion $\left[\mathbf{M}^{+\cdot}-\mathbf{R}_{2}\right]^{+}$at $m / z 219$, the great stability of the benzyl radical (originally present in compound 3 ) accounts for its easy formation. The result shows that is not only the $\left[\mathrm{M}^{+\cdot}-\mathrm{R}_{2}\right]^{+}$ion is the base peak, but also that this procedure masks the formation of $\left[\mathrm{M}^{+\cdot}-\right.$ $\left.\mathrm{NH}_{3}\right]^{+\cdot}$. On the other hand, for compound $\mathbf{1}$, the lower stability of the radical $\mathrm{CH}_{3}$ compared to that of the benzyl radical makes this fragmentation more difficult. In this case the base peak is the $\left[\mathrm{M}^{+\cdot}-\mathrm{NH}_{3}\right]^{+\cdot}$ ion.

Concerning the effect of the nature of the $\mathrm{R}_{1}$ group on the intensity of the $\left[\mathrm{M}^{+\cdot}-\mathrm{R}_{2}\right]^{+}$ion, it emerges from the comparison of the fragmentations of compounds $\mathbf{2}$ and $\mathbf{5}$ that the presence of a methyl group in compound 2 enhances the formation of the $\left[\mathrm{M}^{+\cdot}-\mathrm{R}_{2}\right]^{+}$ion, which constitutes the base peak. On the other hand, for compound $\mathbf{5}$, the lower substitution degree of the $\left[\mathrm{M}^{+\cdot}-\mathrm{R}_{2}\right]^{+}$cation inhibits its formation and accordingly the $\left[\mathrm{M}^{+\cdot}-\mathrm{NH}_{3}\right]^{+\cdot}$ ion is then the base peak.

It is particularly interesting to note that the $\left[\mathrm{M}^{+\cdot}-\mathrm{R}_{2}\right]^{+}$and $\left[\mathrm{M}^{+\cdot}-\mathrm{NH}_{3}\right]^{+\cdot}$ ions fragment respectively by loss of $\mathrm{NH}_{3}$ or $\mathrm{R}_{2}^{\cdot}$ to lead to a third characteristic fragment ion of lower intensity $\left[\mathrm{M}^{+\cdot}-\mathrm{R}_{2}-\mathrm{NH}_{3}\right]^{+}$.

The latter then loses HCN molecule, a hypothesis confirmed by the systematic observation of an ion with $\left[\mathrm{M}^{+\cdot}-\mathrm{R}_{2}-\mathrm{NH}_{3}-27\right]^{+}$. This loss of a $\mathrm{HCN}$ molecule was otherwise already reported in relation with benzylamines fragmentation [17].

In addition to these ions, which confirm unambiguously the structure of these molecules, the other fragments reported in Table 3 result from cleavage in $\alpha$ or $\beta$ positions of the heterocycle, a classic type of fragmentation of molecules with oxygenated heterocycles [14,21].

The structure and chemical composition of the characteristic fragments of molecules $\mathbf{1}$ to $\mathbf{6}$ are presented in Table 3.

It is noteworthy to mention that the cleavage in $\beta$ position of the molecular ion is induced by the loss of the $\mathrm{NH}_{2}$ radical. The following fragments were observed: the fragment ion $\left[\mathrm{CH}_{2}=\mathrm{NH}_{2}\right]^{+}$at $m / z 30$ with an intensity that can reach $98 \%$. This fragment was already observed during the fragmentation of various amines [16,17], and the ion $m / z 96$ (see Table 3). This ion fragments by loss of CO to yield the ion $m / z 68$ which further decomposes by loss of $\mathrm{CH}_{2} \mathrm{NH}$ to give ion $\mathrm{C}_{3} \mathrm{H}_{3}^{+}$at $m / z 39$. It is to be noted that the fragment with the lowest mass always carries the positive charge. 
Table 3

Relative intensities (\%) and composition of the characteristic ions of 1-6

\begin{tabular}{|c|c|c|c|c|c|c|c|c|c|}
\hline & $1.4: 1$ & & , & (1) & s: & 14 & 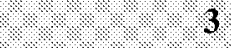 & I. & : \\
\hline Ion & Composition & $m$ & $\%$ & Composition & $m / z$ & $\%$ & Composition & $m / z$ & $\%$ \\
\hline$\left[\mathrm{M}^{+\bullet}\right]^{+\bullet}$ & {$\left[\mathrm{C}_{13} \mathrm{H}_{18} \mathrm{~N}_{2} \mathrm{O}_{2}\right]^{+\bullet}$} & 234 & 0,5 & {$\left[\mathrm{C}_{15} \mathrm{H}_{22} \mathrm{~N}_{2} \mathrm{O}_{2}\right]^{+*}$} & 262 & - & {$\left[\mathrm{C}_{19} \mathrm{H}_{22} \mathrm{~N}_{2} \mathrm{O}_{2}\right]^{+*}$} & 310 & - \\
\hline$\left[\mathrm{M}^{+\bullet}-\mathrm{NH}_{2}{ }^{*}\right]^{+}$ & {$\left[\mathrm{C}_{13} \mathrm{H}_{16} \mathrm{NO}_{2}\right]^{+}$} & 218 & 3 & {$\left[\mathrm{C}_{15} \mathrm{H}_{20} \mathrm{NO}_{2}\right]^{+}$} & 246 & 8 & {$\left[\mathrm{C}_{19} \mathrm{H}_{20} \mathrm{NO}_{2}\right]^{+}$} & 294 & 1 \\
\hline$\left[\mathrm{M}^{+\bullet}-\mathrm{R}_{2}^{*}\right]^{+}$ & {$\left[\mathrm{C}_{12} \mathrm{H}_{15} \mathrm{~N}_{2} \mathrm{O}_{2}\right]^{+}$} & 219 & 17 & {$\left[\mathrm{C}_{12} \mathrm{H}_{15} \mathrm{~N}_{2} \mathrm{O}_{2}\right]^{+}$} & 219 & 100 & {$\left[\mathrm{C}_{12} \mathrm{H}_{15} \mathrm{~N}_{2} \mathrm{O}_{2}\right]^{+}$} & 219 & 100 \\
\hline$\left[\mathrm{M}^{+\bullet}-\mathrm{NH}_{3}\right]^{+\bullet}$ & {$\left[\mathrm{C}_{13} \mathrm{H}_{15} \mathrm{NO}_{2}\right]^{+\bullet}$} & 217 & 100 & {$\left[\mathrm{C}_{15} \mathrm{H}_{19} \mathrm{NO}_{2}\right]^{+\bullet}$} & 245 & 49 & {$\left[\mathrm{C}_{19} \mathrm{H}_{19} \mathrm{NO}_{2}\right]^{+\bullet}$} & 293 & - \\
\hline$\left[\mathrm{M}^{+\bullet}-\mathrm{R}_{2}{ }^{\bullet}-\mathrm{NH}_{3}\right]^{+}$ & {$\left[\mathrm{C}_{12} \mathrm{H}_{12} \mathrm{NO}_{2}\right]^{+}$} & & 52 & {$\left[\mathrm{C}_{12} \mathrm{H}_{12} \mathrm{NO}_{2}\right]^{+}$} & 202 & 27 & {$\left[\mathrm{C}_{12} \mathrm{H}_{12} \mathrm{NO}_{2}\right]^{+}$} & 202 & 10 \\
\hline$\left[\mathrm{M}^{+\bullet}-\mathrm{R}_{2}{ }^{\bullet}-\mathrm{NH}_{3}-\mathrm{HCN}\right]^{+}$ & {$\left[\mathrm{C}_{11} \mathrm{H}_{11} \mathrm{O}_{2}\right]^{+}$} & 175 & 28 & {$\left[\mathrm{C}_{11} \mathrm{H}_{11} \mathrm{O}_{2}\right]^{+}$} & 175 & 21 & {$\left[\mathrm{C}_{11} \mathrm{H}_{11} \mathrm{O}_{2}\right]^{+}$} & 175 & 13 \\
\hline$\left.-\mathrm{CH}_{2}-\mathrm{NH}_{2}\right]^{+}$ & {$\left[\mathrm{C}_{5} \mathrm{H}_{6} \mathrm{NO}\right]^{+\bullet}$} & 96 & 22 & {$\left[\mathrm{C}_{5} \mathrm{H}_{6} \mathrm{NO}\right]^{+o}$} & & 13 & {$\left[\mathrm{C}_{5} \mathrm{H}_{6} \mathrm{NO}\right]^{+\bullet}$} & 96 & 8 \\
\hline$\left[\triangle \mathrm{CH}_{2}-\mathrm{NH}_{2}\right]^{+}$ & {$\left[\mathrm{C}_{4} \mathrm{H}_{6} \mathrm{~N}\right]^{+*}$} & & 5 & {$\left[\mathrm{C}_{4} \mathrm{H}_{6} \mathrm{~N}\right]^{+\bullet}$} & & 6 & {$\left[\mathrm{C}_{4} \mathrm{H}_{6} \mathrm{~N}\right]^{+\bullet}$} & 68 & 3 \\
\hline$[\triangle]^{+}$ & {$\left[\mathrm{C}_{3} \mathrm{H}_{3}\right]^{+}$} & 39 & 5 & {$\left[\mathrm{C}_{3} \mathrm{H}_{3}\right]^{+}$} & 39 & 8 & {$\left[\mathrm{C}_{3} \mathrm{H}_{3}\right]^{+}$} & 39 & 4 \\
\hline$\left[\mathrm{CH}_{2}=\mathrm{NH}_{2}{ }^{+}\right]^{+}$ & {$\left[\mathrm{CH}_{4} \mathrm{~N}\right]^{+}$} & & 22 & {$\left[\mathrm{CH}_{4} \mathrm{~N}\right]^{+}$} & 30 & 83 & {$\left[\mathrm{CH}_{4} \mathrm{~N}\right]^{+}$} & 30 & 32 \\
\hline
\end{tabular}

\begin{tabular}{|c|c|c|c|c|c|c|c|c|c|}
\hline & 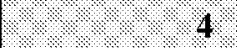 & ? & ?: & is: & . & & 14.6 .6 & & \\
\hline Ion & Composition & $m / z$ & $\%$ & Composition & $m / z$ & $\%$ & Composition & $m / z$ & $\%$ \\
\hline$\left[\mathrm{M}^{+\bullet}\right]^{+\bullet}$ & {$\left[\mathrm{C}_{15} \mathrm{H}_{22} \mathrm{~N}_{2} \mathrm{O}_{2}\right]^{+\bullet}$} & 262 & 0,4 & {$\left[\mathrm{C}_{14} \mathrm{H}_{20} \mathrm{~N}_{2} \mathrm{O}_{2}\right]^{+\bullet}$} & 248 & 0,8 & {$\left[\mathrm{C}_{17} \mathrm{H}_{18} \mathrm{~N}_{2} \mathrm{O}_{2}\right]^{+\bullet}$} & 282 & - \\
\hline$\left[\mathrm{M}^{+\bullet}-\mathrm{NH}_{2}{ }^{\bullet}\right]^{+}$ & {$\left[\mathrm{C}_{15} \mathrm{H}_{20} \mathrm{NO}_{2}\right]^{+}$} & 246 & 4 & {$\left[\mathrm{C}_{14} \mathrm{H}_{18} \mathrm{NO}_{2}\right]^{+}$} & 232 & 10 & {$\left[\mathrm{C}_{17} \mathrm{H}_{16} \mathrm{NO}_{2}\right]^{+}$} & 266 & 5 \\
\hline$\left[\mathrm{M}^{+\bullet}-\mathrm{R}_{2}\right]^{+}$ & {$\left[\mathrm{C}_{13} \mathrm{H}_{17} \mathrm{~N}_{2} \mathrm{O}_{2}\right]^{+}$} & 233 & 100 & {$\left[\mathrm{C}_{11} \mathrm{H}_{13} \mathrm{~N}_{2} \mathrm{O}_{2}\right]^{+}$} & 205 & 84 & {$\left[\mathrm{C}_{11} \mathrm{H}_{11} \mathrm{~N}_{2} \mathrm{O}_{2}\right]^{+}$} & 205 & 1 \\
\hline$\left[\mathrm{M}^{+\bullet}-\mathrm{NH}_{3}\right]^{+\bullet}$ & {$\left[\mathrm{C}_{15} \mathrm{H}_{19} \mathrm{NO}_{2}\right]^{+\bullet}$} & 245 & 33 & {$\left[\mathrm{C}_{14} \mathrm{H}_{17} \mathrm{NO}_{2}\right]^{+\bullet}$} & 231 & 100 & {$\left[\mathrm{C}_{17} \mathrm{H}_{15} \mathrm{NO}_{2}\right]^{+\bullet}$} & 265 & 100 \\
\hline$\left[\mathrm{M}^{+*}-\mathrm{R}_{2}{ }^{*}-\mathrm{NH}_{3}\right]^{+}$ & {$\left[\mathrm{C}_{13} \mathrm{H}_{14} \mathrm{NO}_{2}\right]^{+}$} & 216 & 18 & {$\left[\mathrm{C}_{11} \mathrm{H}_{10} \mathrm{NO}_{2}\right]^{+}$} & 188 & 68 & {$\left[\mathrm{C}_{11} \mathrm{H}_{10} \mathrm{NO}_{2}\right]^{+}$} & 188 & 5 \\
\hline$\left[\mathrm{M}^{+*}-\mathrm{R}_{2}{ }^{-}-\mathrm{NH}_{3}-\mathrm{HCN}\right]^{+}$ & {$\left[\mathrm{C}_{12} \mathrm{H}_{13} \mathrm{O}_{2}\right]^{+}$} & 189 & 18 & {$\left[\mathrm{C}_{10} \mathrm{H}_{9} \mathrm{O}_{2}\right]^{+}$} & 161 & 62 & {$\left[\mathrm{C}_{10} \mathrm{H}_{9} \mathrm{O}_{2}\right]^{+}$} & 161 & 3 \\
\hline $\left.\mathrm{H}_{2}-\mathrm{NH}_{2}\right]^{+}$ & {$\left[\mathrm{C}_{5} \mathrm{H}_{6} \mathrm{NO}\right]^{+\bullet}$} & 96 & 19 & {$\left[\mathrm{C}_{5} \mathrm{H}_{6} \mathrm{NO}\right]^{+\circ}$} & 96 & 25 & {$\left[\mathrm{C}_{5} \mathrm{H}_{6} \mathrm{NO}^{+\bullet}\right.$} & 96 & 34 \\
\hline$\left[\triangleq \mathrm{CH}_{2}-\mathrm{NH}_{2}\right]^{+}$ & {$\left[\mathrm{C}_{4} \mathrm{H}_{6} \mathrm{~N}\right]^{+\bullet}$} & 68 & 4 & {$\left[\mathrm{C}_{4} \mathrm{H}_{6} \mathrm{~N}\right]^{+\bullet}$} & 68 & 11 & {$\left[\mathrm{C}_{4} \mathrm{H}_{6} \mathrm{~N}\right]^{+\bullet}$} & 68 & 4 \\
\hline$[\triangle]^{+}$ & {$\left[\mathrm{C}_{3} \mathrm{H}_{3}\right]^{+}$} & 39 & 5 & {$\left[\mathrm{C}_{3} \mathrm{H}_{3}\right]^{+}$} & 39 & 12 & {$\left[\mathrm{C}_{3} \mathrm{H}_{3}\right]^{+}$} & 39 & 6 \\
\hline$\left[\mathrm{CH}_{2}=\mathrm{NH}_{2}{ }^{+}\right]^{+}$ & {$\left[\mathrm{CH}_{4} \mathrm{~N}\right]^{+o}$} & 30 & 51 & {$\left[\mathrm{CH}_{4} \mathrm{~N}\right]^{+o}$} & 30 & 98 & {$\left[\mathrm{CH}_{4} \mathrm{~N}\right]^{+o}$} & 30 & 64 \\
\hline
\end{tabular}


If we compare the ei-ms for $\mathbf{1}$ to $\mathbf{6}$ to the es-ms we noticed that the molecular radical ion was almost inexistant using the ei-ms, whereas using the es-ms, the counterpart of the molecular radical ion, that is to say the protonated molecular ion, was the base peak for all the compounds analyzed.

In the es-ms, the fragmentation routes are governed by the loss of ammonia from the $[\mathrm{M}+\mathrm{H}]^{+}$quasimolecular ion, which are increased by increasing the fragmentation voltages, to afford the $\left[\mathrm{M}+\mathrm{H}-\mathrm{NH}_{3}\right]^{+}$. This is not the case for the ei-ms which afford simultaneously the ions $\left[\mathrm{M}^{+\cdot}-\mathrm{R}_{2}\right]^{+}$and $\left[\mathrm{M}^{+\cdot}-\mathrm{NH}_{3}\right]^{+\cdot}$ as mentioned before.

\section{Conclusion}

The analysis of the mass spectra obtained by electronic impact allowed us to rationalize the fragmentation pathways of various difurfurylic diamines. The molecular radical ions are either absent or inexistant in all cases. Elsewhere, we have the simultaneous formation of the ions $\left[\mathrm{M}^{+\cdot}-\mathrm{R}_{2}^{*}\right]^{+}$and $\left[\mathrm{M}^{+\cdot}-\mathrm{NH}_{3}\right]^{+\cdot}$.

\section{References}

[1] A. Gandini, Encyclopedia of Polymer Science and Engineering, Vol. 7, 2nd edn, 1986, pp. 454-473.

[2] A. Gandini, Comprehensive Polymer Science, G. Allen, ed., Pergamon Press, Oxford, 1992.

[3] A. Lesimple, Y. Le Bigot, M. Delmas, A. Gaset and G. Roux, Fr 2679559 and Pct Int. Appl. WO 93/02.071, CA: 118: 254737f (1993).

[4] A. Lesimple, Y. Le Bigot, M. Delmas, A. Gaset and G. Roux, Fr 2679560 and Pct Int. Appl. WO 93/02.072, CA: 118: $254738 \mathrm{~g}(1993)$.

[5] M. Skouta, A. Lesimple, Y. Le Bigot and M. Delmas, Synth. Comm. 24 (1994), 2571-2576.

[6] Z. Hui and A. Gandini, Eur. Polym. J. 28 (1992), 1461-1469.

[7] M.S. Holfinger, A.H. Conner, L.F. Lorenz and C.G. Hill, J. of Appl. Polym. Sc. 49 (1993), 337-344.

[8] S. Boufi, M.N. Belgacem, J. Quillerou and A. Gandini, Macromolecules 26 (1993), 6706-6717.

[9] M.N. Belgacem, S. Boufi, A. Gandini and J. Quillerou, Biomass for Energy and Industry, 7th EC Conference, Ponte Press, 1994, pp. 317-325.

[10] A. Mitiakoudis and A. Gandini, Macromolecules 24 (1991), 830-835. A. Mitiakoudis, A. Gandini and H. Cheradame, Polymer Communication 26 (1985), 246-249.

[11] X. He, A. Conner and J.A. Koutsky, J. Poly. Sci., Polym. Chem. Ed. 30 (1992), 533.

[12] E. Gentil, A. Lesimple, Y. Le Bigot, M. Delmas and J. Banoub, Rapid Comm. Mass Spectrom. 8 (1995), 869-875.

[13] J.L. Cawse, J.L. Stanford and R.H. Still, Makromol. Chem. 185 (1984), 697.

[14] Q.N. Porter, Mass Spectr. of Heterocycl. Comp., 2nd edn, J. Wiley and Sons, 1985.

[15] A. Ferreti, V.P. Flanagan and J.M. Ruth, J. Agric. Food Chem. 22 (1974), 729-731; Org. Mass Spectr. 8 (1974), $403-407$. E.D. Loughran, E.M. Wewerka and G.J. Hammons, J. Heterocycl. Chem. 9 (1972), 57-65. P.H. Boyle, W. Cocker, T.B.H. McMurry and A.C. Pratt, J. Chem. Soc. (C) (1967), 1993-1998.

[16] F.W. McLafferty, Interpr. of Mass Spectra, 3rd edn, University Science Books, 1980.

[17] M.W. Couch and C.M. William, Org. Mass Spectr. 6 (1972), 21-32.

[18] J.A. Kerr, Chem. Rev. 66 (1966), 465.

[19] S.W. Benson, J. Chem. Educ. 42 (1965), 502.

[20] C. Leroy, D. Peeters and C. Wilante, Theochem. 5 (1982), 217.

[21] C. Mercier, Bull. Soc. Chim. Fr. 12 (1969), 4545-4560. 


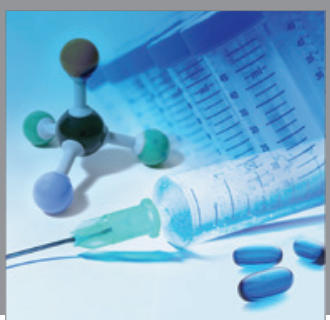

International Journal of

Medicinal Chemistry

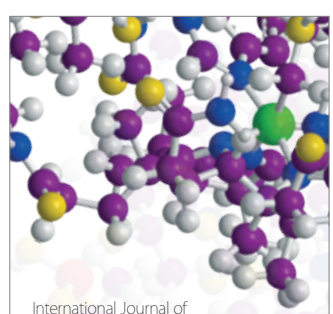

Carbohydrate Chemistry

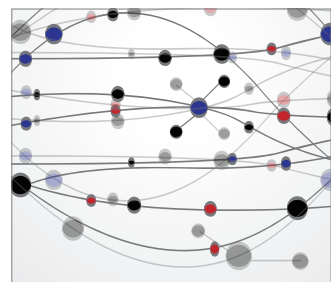

The Scientific World Journal
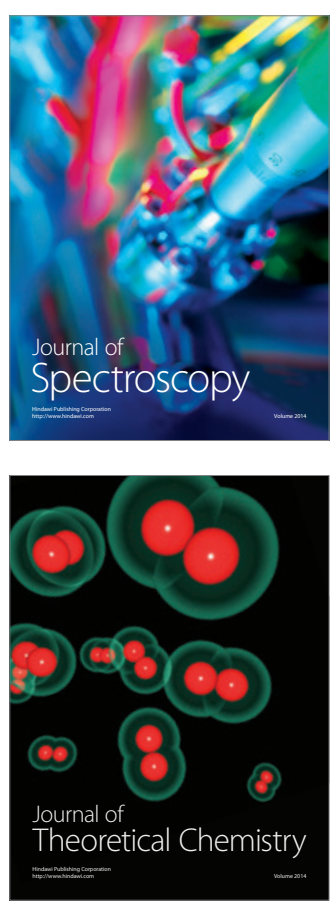
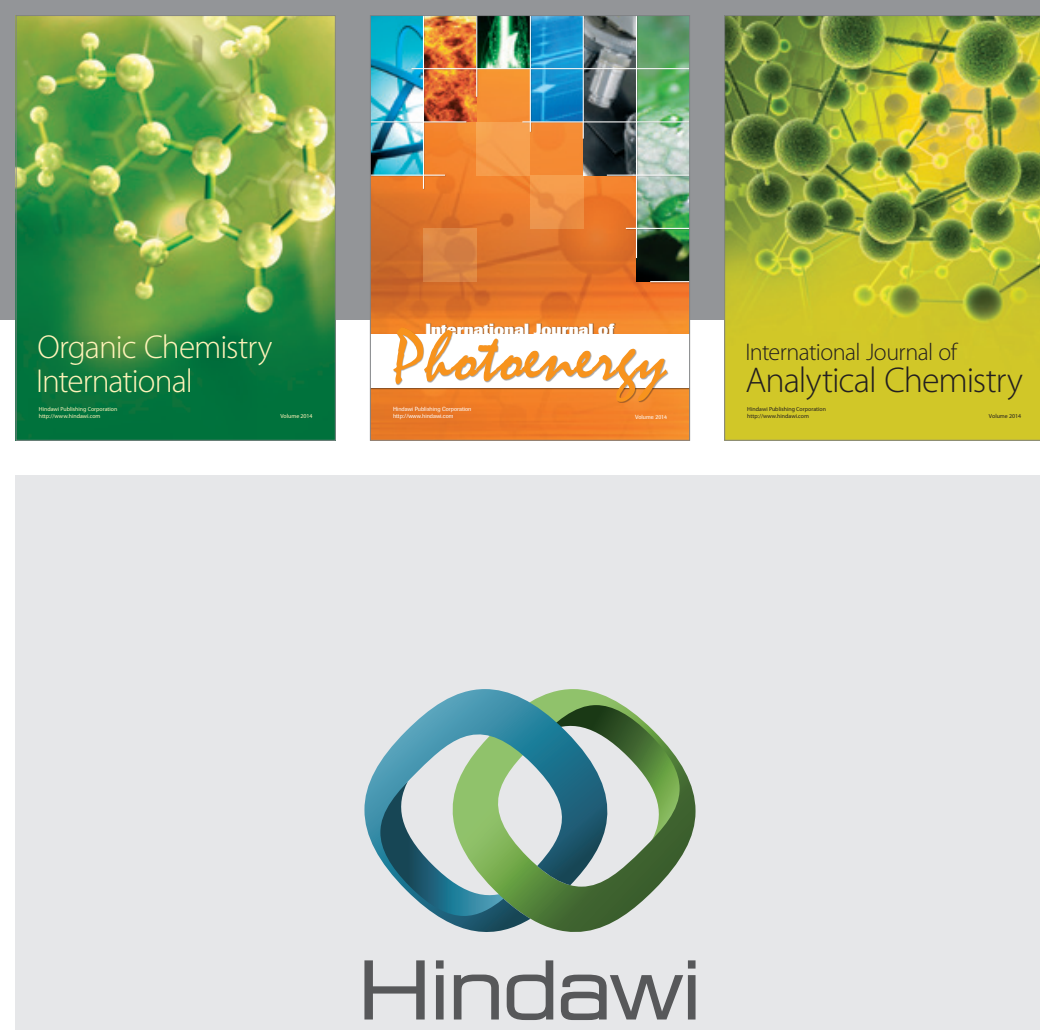

Submit your manuscripts at

http://www.hindawi.com
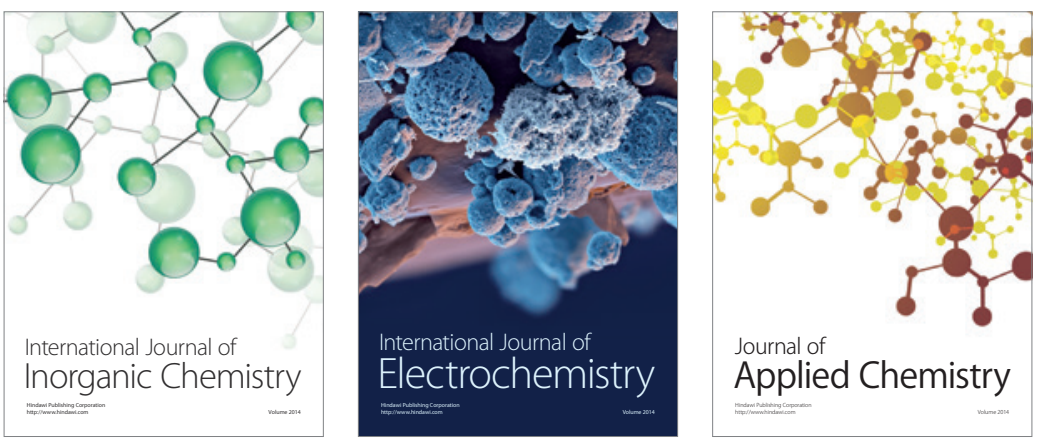

Journal of

Applied Chemistry
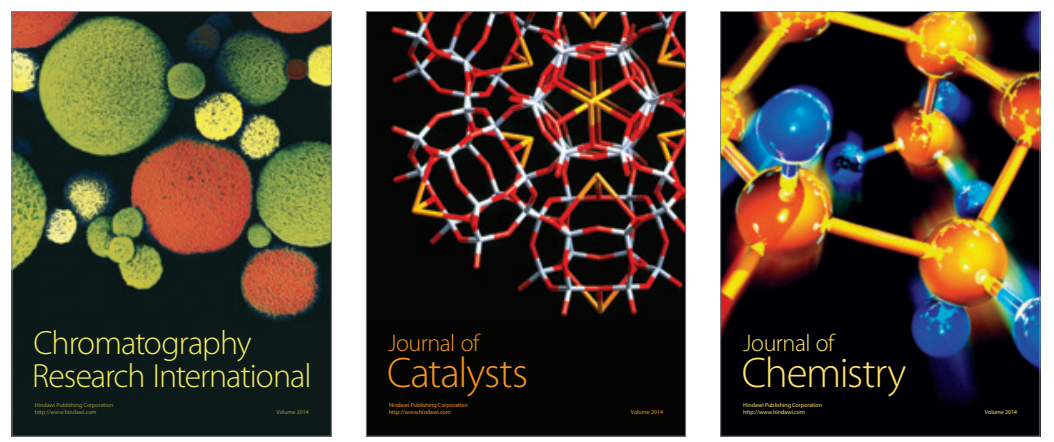
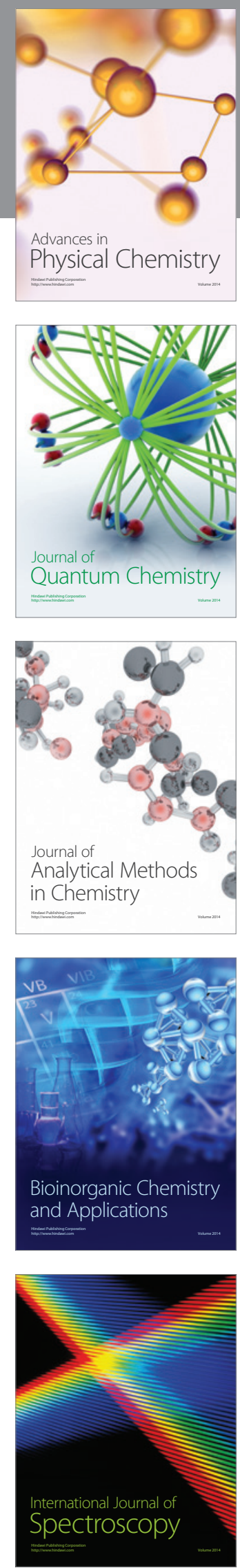